\title{
PENGARUH FOTOAUTOTROFIK TERHADAP PERTUMBUHAN TUNAS KRISAN DALAM PROSES KULTUR IN VITRO SERTA PERBEDAAN STOMATA INVITRO DAN EXVITRO KRISAN
}

\author{
Siti Hartati Yusida Saragih, Khairul Rizal, Kamsia Dorliana Sitanggang \\ Program Studi Agroteknologi, Fakultas Sains dan Teknologi, Universitas Labuhanbatu \\ Jl. SM. Raja No. 126A Rantauprapat, Sumatera Utara \\ Email : yusida90.shys@gmail.com
}

\begin{abstract}
Chrysanthemum (Chrysanthemum indicum L.) is an ornamental plant that is included in an important contribution in the ornamental plant business. Related to chrysanthemum buds grown in vitro in culture tubes or bottles with a tightly closed to avoid bacterial and fungal contamination and to protect the humidity of the culture environment. However, this tight cap often affects the composition of the gas in a jar or bottle, which inhibits plant growth. The purpose of this study was to study the effect of photoautotrophic on the growth of chrysanthemum buds in the in vitro culture process and the differences in invitro and exvitro chrysanthemum stomata. This research was conducted in March 2016 to May 2016 in the Microtechnical Laboratory, IPB University. Research results obtained from research on the position given to research conducted on the number of roots, the number of books and the number of shoots. The influence of the environment of exvitro also significantly affects the number of stomata, stomata width and stomata density.
\end{abstract}

Keywords :ex vitro, in vitro, photoautotrophic

\section{PENDAHULUAN}

\subsection{Latar Belakang}

Krisan (Chrysanthemum indicum

L.) merupakan tumbuhan yang dimanfaatkan sebagai tanaman hias maupun bahan baku obat. Tanaman hias ini termasuk kedalam komoditas penting dalam bisnis tanaman hias. Pengembangan krisan perlu terus diupayakan dalam upaya pemenuhan selera konsumen (Rukmana dan Mulyana, 1997). Salah satu metode perbanyakan masal yang digunakan dalam budidaya krisan adalah secara in vitro.
Tanaman yang ditumbuhkan secara in vitro biasanya diletakkan dalam tabung atau botol kultur dengan tutup rapat untuk menghindari kontaminasi bakteri dan jamur serta untuk menjaga kelembaban lingkungan kultur. Akan tetapi tutup yang rapat tersebut sering mempengaruhi komposisi gas di dalam tabung atau botol sehingga menghambat pertumbuhan tanaman. Oleh karena itu udara di dalam tabung atau botol berbeda dengan udara $e x$ vitro sehingga sering menyebabkan malfungsi stomata, rendahnya kandungan klorofil, memanjangnya daun serta hiperhidrasi. Kondisi yang demikian 
mengakibatkan laju multiplikasi dan daya hidup tanaman menjadi rendah (Kitaya, 2005).

Untuk meningkatkan kualitas udara dan meminimalkan perbedaan udara di dalam dan di luar lingkungan kultur dapat digunakan wadah kultur yang dilengkapi dengan ventilasi. Penggunaan ventilasi biasanya merupakan bagian dari mikropropagasi fotoautropik, yaitu suatu sistem mikropropagasi yang memanfaatkan bahan anorganik endogen untuk memenuhi kebutuhan tanaman dengan menggunakan cahaya sebagai sumber energi. Namun sering terjadi resiko kontaminasi dan menghasilkan plantlet dengan persentase hidup yang rendah pada tahap aklimatisasi (Kozai \& Kubota, 2005). Oleh karena itu penggunaan teknik in vitro untuk perbanyakan tanaman krisan masih perlu dioptimalkan.

Autotrof adalah organisme yang mampu menyediakan atau mensintesis makanan sendiri yang berupa bahan organik dari bahan anorganik dengan bantuan energi seperti matahari dan kimia. Komponen autotrof berfungsi sebagai produsen. Bila sumber energi berasal dari matahari maka disebut fotoautotrof. Hal ini terjadi pada tanaman yang dikulturkan secara in-vitro, karena semua bahan yang menunjang kehidupan tanaman tersebut tersedia sehingga tanaman dapat melakukan proses kehidupannya sama seperti halnya bila tanaman tumbuh di tanah (Kozai, et al1992).

Dalam teknik fotoautotrofik, tanaman mampu mengendalikan transpirasi sehingga tidak terjadi kehilangan air dan kelayuan saat dipindah ke lingkungan ex vitro walaupun tanpa aklimatisasi secara khusus (Kozai \& Zobayed, 2000, Lucchesini et al., 2001). Hal ini diduga karena pada teknik fotoautotrofik: 1) tingkat fotosintesis bersih lebih tinggi sehingga akumulasi karbohidrat lebih besar, 2) tingkat transpirasi dan penyerapan mineral dalam medium lebih tinggi, dan 3) porositas udara dari bahan pengisi memberikan konsentrasi oksigen terlarut lebih tinggi di sekitar dasar tunas sehingga pertumbuhan akar lebih optimal (Rahayu, 2015).

Stomata atau mulut daun adalah komponen sel epidermis daun yang berperan sebagai lintasan masuk keluarnya $\mathrm{CO}_{2}, \mathrm{O}_{2}$ dan $\mathrm{H}_{2} \mathrm{O}$ selama berlangsungnya fotosíntesis dan respirasi (Woelanningsih, 1984). Oleh karena itu, aktivitas fotosintesis sangat bergantung antara lain pada pembukaan dan penutupan stomata. Selain melalui stomata, transpirasi juga dapat berlangsung melalui kutikula. Namun, transpirasi melalui stomata lebih banyak daripada melalui kutikula epidermis (Palit, 2008).

Pengamatan stomata dapat digunakan sebagai seleksi secara genetika 
untuk produksi ataupun ketahanan tanaman terhadap hama dan penyakit. Selain dipengaruhi secara genétika, perkembangan dan jumlah stomata dipengaruhi oleh lingkungan (Noggle dan Fritz, 1983). Tanaman yang tumbuh pada lingkungan kering dengan intensitas cahaya yang tinggi cenderung memiliki stomata yang banyak, tetapi ukurannya kecil dibanding dengan tanaman yang tumbuh pada lingkungan basah dan terlindung (Prawiranata et al., 1981).

\subsection{Tujuan}

Tujuan penelitian ini adalah mengetahui pengaruh fotoautotrofik terhadap pertumbuhan tunas krisan dalam proses kultur in vitro serta perbedaan stomata invitro dan exvitro krisan.

\section{METODOLOGI PENELITIAN}

\subsection{Lokasi dan Waktu}

Penelitian ini dilakukan dan di Laboratorium Mikroteknik pada tanggal 12 Mei 2016.

\subsection{Metode Fotoautotropik}

Bahan tanaman yang digunakan adalah eksplan krisan. Media yang digunakan yaitu media $\mathrm{MS}_{2}, \mathrm{MS}_{2 \mathrm{a}}\left(\mathrm{MS}_{2}+\right.$ $20 \mathrm{~g} / \mathrm{l}$ gula) dan $\mathrm{MS}_{2 \mathrm{~b}}\left(\mathrm{MS}_{2}+10 \mathrm{~g} / \mathrm{l}\right.$ gula $)$. Alat yang digunakan adalah botol kultur, scapel, pinset, gunting, petridish dan bunsen.

Penanaman dilakukan di Laminar Air Flow dengan menanam satu pucuk krisan dan dua mata tunas aksilar pada masing-masing media yang digunakan. Pemberian ventilasi dilakukan pada plastik berlubang dan diberikan filter warna putih. Perlakuan yang dilakukan antara lain: kontrol,ventilasi satu lubang dan ventilasi dua lubang kemudian lubang diberi selotip filter.

Pengamatan dilakukan pada setiap botol yang kontrol, berlubang satu dan berlubang. Peubah-peubah yang diamati pada praktikum ini adalah jumlah buku, jumlah tunas dan jumlah akar.

\subsection{Analisis Data}

Percobaan menggunakan Rancangan Acak Lengkap (RAL) tiga faktor dengan dengan 7 perlakuan dan 3 variabel. Analisis statistik yang digunakan adalah analisis varian (ANOVA) satu arah untuk parameter respons jumlah akar, jumlah buku dan jumlah tunas. Jika berbeda nyata $(\mathrm{P}<0,05)$, dilakukan $\mathrm{Uji}$ LSD.

\subsection{Pengamatan Stomata Pada Tanaman In vitro dan Eks vitro}

Bahan tanaman yang digunakan yaitu daun krisan. Alat yang digunakan selotip bening, preparat, mikroskop dan 
silet. Daun krisan In vitro dan Ex vitro diambil dan dilapis selotip pada gelas preparat dan dilanjutkan dengan membersihkan permukaan daun hingga lapisan tipis menggunakan silet. Setelah permukaan daun terpisah dari jaringan lainnya (tersisa jaringan epidermis bawah daun).

Peubah-peubah yang diamati adalah jumlah stomata, lebar stomata dan kerapatan stomata menggunakan mikroskop dengan perbesaran 40x dengan luas bidang pandang 0,19625 $\mathrm{mm} 2$ dan dilakukan perhitungan kerapatan stomata dengan persamaan berikut:
Kerapatan stomata $=\frac{\text { jumlah stomata }}{\text { luas bidang pandang }}$

\section{HASIL DAN PEMBAHASAN}

\subsection{Morfologi Tunas Krisan}

Tunas krisan yang di tumbuhkan dalam botol kultur dengan tutup berventilasi pada (Gambar 1) dan morfologi tunas pada media $\mathrm{MS}_{2} \mathrm{a}$ dan Media $\mathrm{MS}_{2} \mathrm{~b}$ dengan perlakuan dua lubang terdapat pada (Gambar 2). Penggunaan tutup berventilasi bertujuan untuk memberikan peluang pertukaran udara yang lebih baik ke luar dan ke dalam lingkungan kultur.

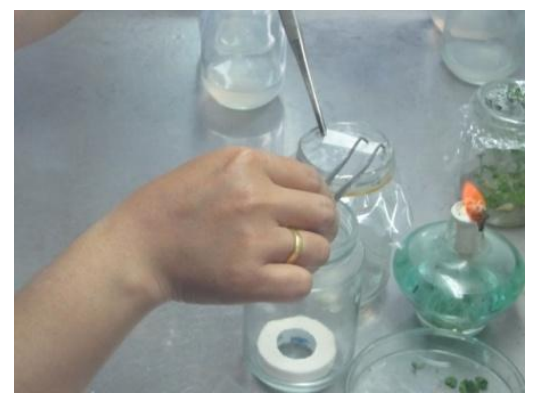

Gambar 1. Tunas krisan dalam botol kultur dengan tutup berventilasi; filter putih
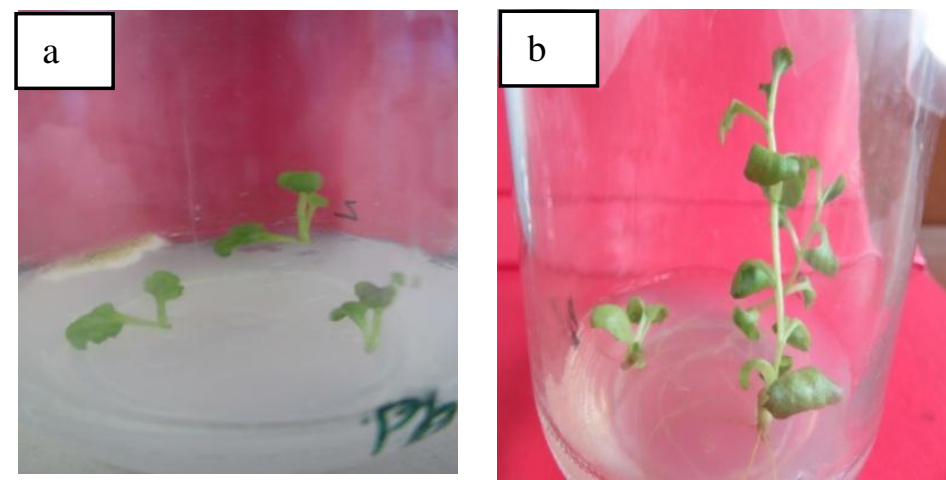

Gambar 2. a. Tunas krisan Pucuk pada media $\mathrm{MS}_{2}$ a dengan 2 lubang.

b. Tunas krisan Pucuk pada media $\mathrm{MS}_{2} \mathrm{~b}$ dengan 2 lubang 


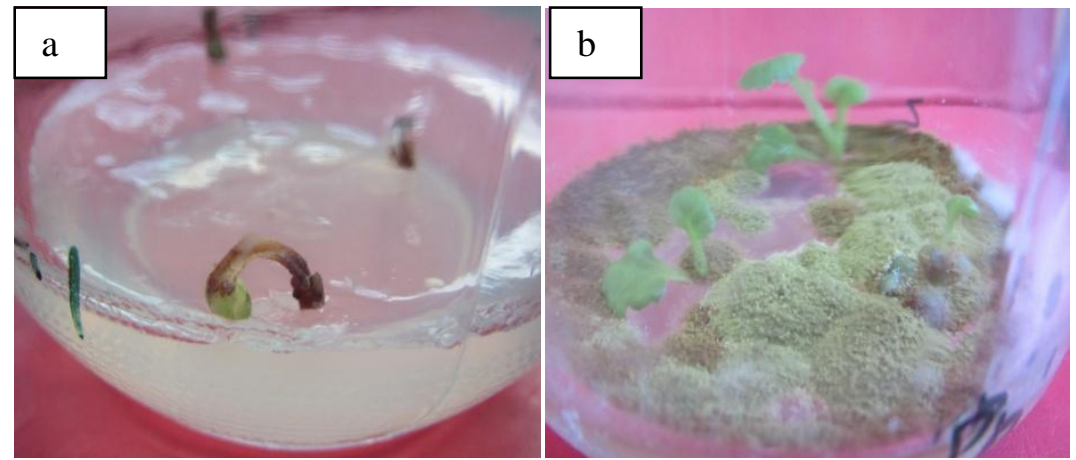

Gambar 3. a. Tunas krisan media $\mathrm{MS}_{2} \mathrm{a}$ Aksilar pada 5 MST. b. Tunas krisan terkontam pada media $\mathrm{MS}_{2}$ a Aksilar 3 MST.

\subsection{Jumlah Akar}

Perlakuan posisi tunas yang diberikan dalam percobaan berpengaruh nyata terhadap pertumbuhan akar dengan nilai 0,0966 (Tabel 1). Hal ini dapat disebabkan oleh adanya lubang sebagai keluar masuknya udara yang mempengaruhi posisi pertumbuhan tunas. Menurut Rahayu (2015), porositas udara dari bahan pengisi memberikan konsentrasi oksigen terlarut lebih tinggi di sekitar dasar tunas sehingga pertumbuhan akar lebih optimal.

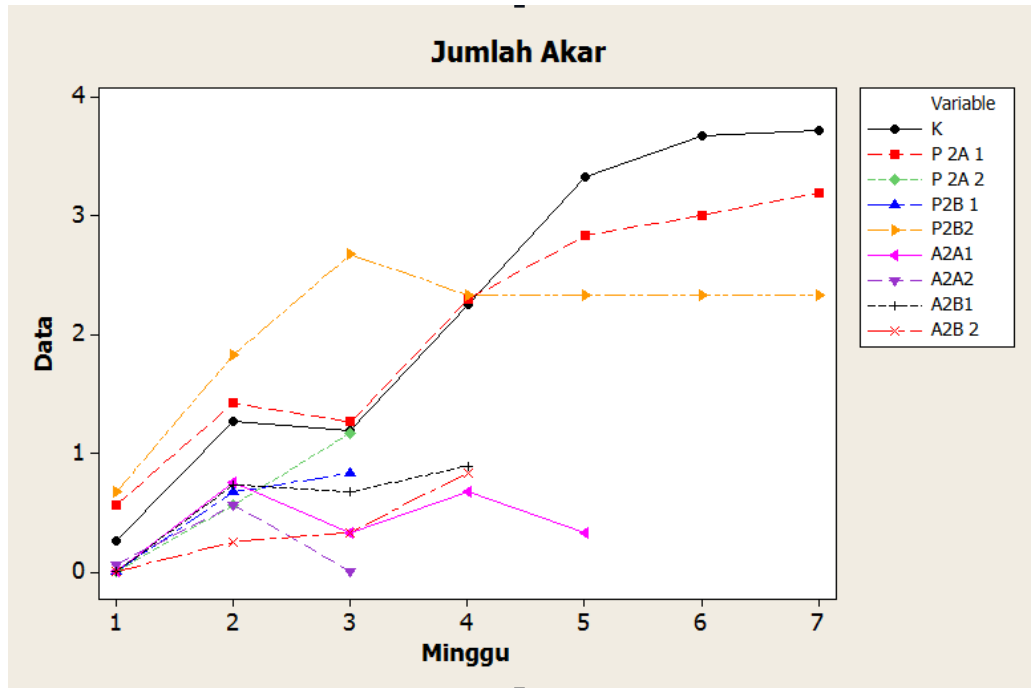

Keterangan: $\mathrm{K}=$ kontrol; $\mathrm{P} 2 \mathrm{~A} 1=$ pucuk pada media $\mathrm{MS}_{2}$ a lubang 1; $\mathrm{P} 2 \mathrm{~A} 2=$ pucuk pada media $\mathrm{MS}_{2} \mathrm{a}$ lubang 2; $\mathrm{P} 2 \mathrm{~B} 1=$ pucuk pada media $\mathrm{MS}_{2} \mathrm{~b}$ lubang $1 ; \mathrm{P} 2 \mathrm{~B} 2=$ pucuk pada media $\mathrm{MS}_{2} \mathrm{~b}$ lubang 2; $\mathrm{A} 2 \mathrm{~A} 1=$ aksilar pada media $\mathrm{MS}_{2}$ a lubang 1; A2A2=aksilar pada media $\mathrm{MS}_{2}$ a lubang 2; A2B1=aksilar pada media $\mathrm{MS}_{2}$ b lubang 1; $\mathrm{A} 2 \mathrm{~B} 2=$ aksilar pada media $\mathrm{MS}_{2}$ b lubang 2

Gambar 4. Grafik Jumlah Akar 
Tabel 1. Jumlah Akar Krisan (2 MST)

\begin{tabular}{llllll}
\hline Sumber Keragaman & $\begin{array}{l}\text { Derajat } \\
\text { bebas }\end{array}$ & $\begin{array}{l}\text { Jumlah } \\
\text { Kuadarat }\end{array}$ & $\begin{array}{l}\text { Kudarat } \\
\text { Tengah }\end{array}$ & F Value & $\operatorname{Pr}(>\mathrm{F})$ \\
\hline Posisi & 2 & 0.4177 & 0.4177 & 2.56 & $0.0966^{*}$ \\
Media & 1 & 0.0002 & 0.0002 & 0.00 & 0.9652 \\
Lubang & 1 & 0.0609 & 0.0609 & 0.75 & 0.3955 \\
Posisi:media & 1 & 0.0301 & 0.0301 & 0.37 & 0.5490 \\
Posisi:lubang & 1 & 0.0151 & 0.0151 & 0.18 & 0.6708 \\
Media:lubang & 1 & 0.0829 & 0.0829 & 1.02 & 0.3226 \\
Posisi:media:lubang & 1 & 0,2646 & 0,2646 & 3.24 & 0.0833 \\
Galat & 26 & 2.1203 & 0.0816 & & \\
Total & 34 & 2.9916 & & & \\
\hline
\end{tabular}

Keterangan: * Signifikan pada taraf $5 \%(\mathrm{P}<0,05)$

\subsection{Jumlah Buku}

Jumlah buku pada tunas krisan dalam percobaan berpengaruh nyata terhadap posisi tunas pada (Tabel 2) dengan nilai 0,0014 . Hal ini disebabkan oleh udara yang diperoleh pada masing- masing posisi tanaman berbeda. Terlihat pada (Gambar 2.b), pertumbuhan tunas yang tidak seragam pada setiap posisi tumbuhnya tunas. Menurut Kozai \& Kubota (2005), penggunaan ventilasi pada mikropropagas fotoautropik memanfaatkan cahaya sebagai sumber energi.

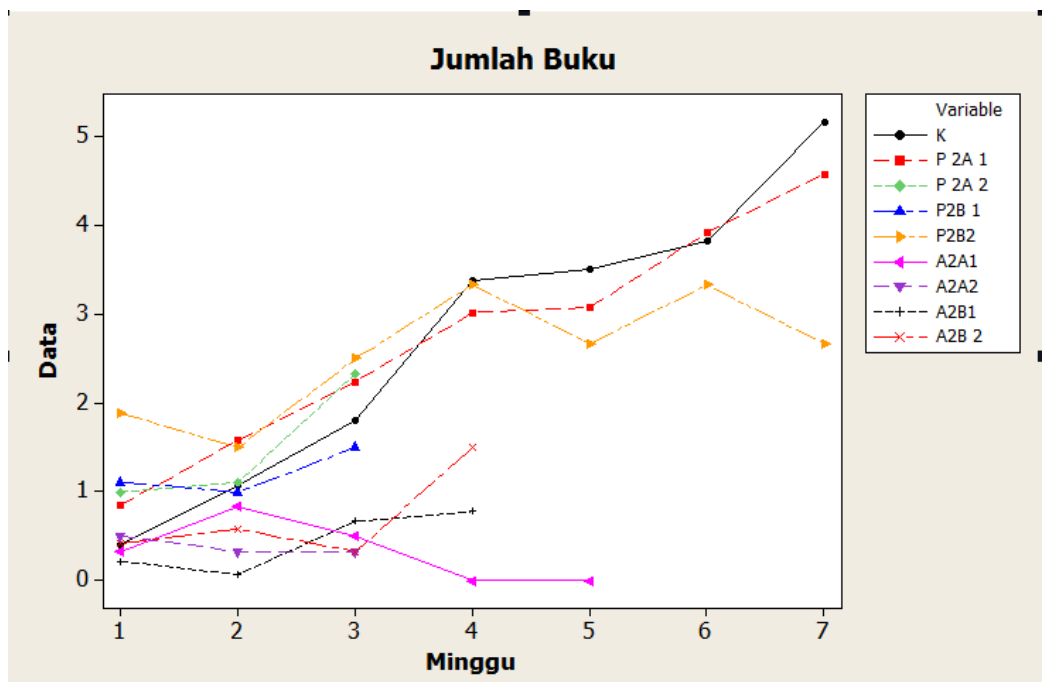

Keterangan: $\mathrm{K}=$ kontrol; $\mathrm{P} 2 \mathrm{~A} 1=$ pucuk pada media $\mathrm{MS}_{2}$ a lubang 1; $\mathrm{P} 2 \mathrm{~A} 2=$ pucuk pada media $\mathrm{MS}_{2} \mathrm{a}$ lubang 2; $\mathrm{P} 2 \mathrm{~B} 1=$ pucuk pada media $\mathrm{MS}_{2}$ b lubang 1; $\mathrm{P} 2 \mathrm{~B} 2=$ pucuk pada media $\mathrm{MS}_{2} \mathrm{~b}$ lubang 2; $\mathrm{A} 2 \mathrm{~A} 1=$ aksilar pada media $\mathrm{MS}_{2}$ a lubang 1; A2A2=aksilar pada media $\mathrm{MS}_{2}$ a lubang 2; A2B1=aksilar pada media $\mathrm{MS}_{2}$ b lubang 1; $\mathrm{A} 2 \mathrm{~B} 2=$ aksilar pada media $\mathrm{MS}_{2}$ b lubang 2

Gambar 5. Grafik Jumlah Buku Krisan 
Tabel 2. Jumlah Buku Krisan (2 MST)

\begin{tabular}{llllll}
\hline Sumber Keragaman & $\begin{array}{l}\text { Derajat } \\
\text { bebas }\end{array}$ & $\begin{array}{l}\text { Jumlah } \\
\text { Kuadarat }\end{array}$ & $\begin{array}{l}\text { Kudarat } \\
\text { Tengah }\end{array}$ & F Value & $\operatorname{Pr}(>\mathrm{F})$ \\
\hline Posisi & 2 & 1.2616 & 0.6308 & 7.98 & $0.0014^{*}$ \\
Media & 1 & 0.0161 & 0.0161 & 0.20 & 0.6547 \\
Lubang & 1 & 0.1057 & 0.1057 & 1.34 & 0.2554 \\
Posisi:media & 1 & 0.1566 & 0.1566 & 1.98 & 0.1680 \\
Posisi:lubang & 1 & 0.0057 & 0.0057 & 0.07 & 0.7890 \\
Media:lubang & 1 & 0.0279 & 0.0279 & 0.35 & 0.5565 \\
Posisi:media:lubang & 1 & 0.0179 & 0.0179 & 0.23 & 0.6372 \\
Galat & 35 & 2.7659 & 0.0790 & & \\
Total & 43 & 4.3573 & & & \\
\hline Keterangan: & Signifikan
\end{tabular}

Keterangan: * Signifikan pada taraf $5 \%(\mathrm{P}<0,05)$

\subsection{Jumlah Tunas}

Perkembangan tunas krisan juga menunjukkan berpengaruh nyata terhadap posisi tumbuh tunas dengan nilai 0,0224 .

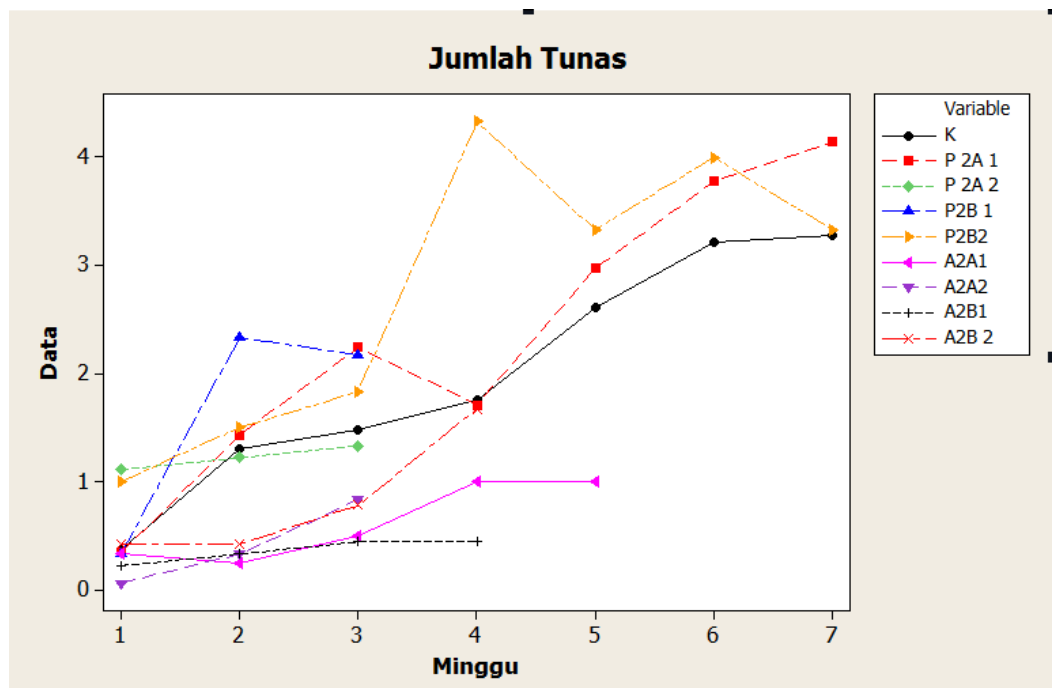

Keterangan: $\mathrm{K}=$ kontrol; $\mathrm{P} 2 \mathrm{~A} 1=$ pucuk pada media $\mathrm{MS}_{2}$ a lubang 1; $\mathrm{P} 2 \mathrm{~A} 2=$ pucuk pada media $\mathrm{MS}_{2} \mathrm{a}$ lubang 2; $\mathrm{P} 2 \mathrm{~B} 1=$ pucuk pada media $\mathrm{MS}_{2}$ b lubang 1; $\mathrm{P} 2 \mathrm{~B} 2=$ pucuk pada media $\mathrm{MS}_{2} \mathrm{~b}$ lubang 2; A2A1=aksilar pada media $\mathrm{MS}_{2}$ a lubang 1; A2A2=aksilar pada media $\mathrm{MS}_{2}$ a lubang 2; A2B1=aksilar pada media $\mathrm{MS}_{2}$ b lubang 1; A2B2=aksilar pada media $\mathrm{MS}_{2}$ b lubang 2

Gambar 6. Grafik Jumlah Tunas 
Tabel 3. Jumlah Tunas (2 MST)

\begin{tabular}{llllll}
\hline Sumber Keragaman & $\begin{array}{l}\text { Derajat } \\
\text { bebas }\end{array}$ & $\begin{array}{l}\text { Jumlah } \\
\text { Kuadarat }\end{array}$ & Kudarat Tengah & F Value & $\operatorname{Pr}(>\mathrm{F})$ \\
\hline Posisi & 2 & 1.2452 & 1.2452 & 4.41 & $0.0224^{*}$ \\
Media & 1 & 0.0626 & 0.0626 & 0.44 & 0.5113 \\
Lubang & 1 & 0.0036 & 0.0036 & 0.03 & 0.8746 \\
Posisi:media & 1 & 0.0370 & 0.0370 & 0.26 & 0.6126 \\
Posisi:lubang & 1 & 0.0324 & 0.0324 & 0.23 & 0.6359 \\
Media:lubang & 1 & 0.0115 & 0.0115 & 0.08 & 0.7777 \\
Posisi:media:lubang & 1 & 0.0180 & 0.0180 & 0.13 & 0.7237 \\
Galat & 26 & 3.6669 & 0.1410 & & \\
Total & 34 & 5.0771 & & & \\
\hline Ketangan & $*$ Signifis
\end{tabular}

Keterangan: * Signifikan pada taraf $5 \%(\mathrm{P}<0,05)$

Pada (Gambar 4, 5 dan 6) terlihat bahwa parameter jumlah akar, jumlah buku dan jumlah tunas memiliki pertambahan jumlah yang sama yaitu pada perlakuan kontrol, media $\mathrm{MS}_{2} \mathrm{a}$ dengan eksplan pucuk lubang satu dan media $\mathrm{MS}_{2} \mathrm{~b}$ dengan eksplan pucuk lubang dua dan masing-masing parameter memiliki pertambahan jumlah akar yang normal hingga 7 MST. Berbeda dengan perlakuan menggunakan pucuk, pada pucuk (Gambar 3.a) menunjukkan kematian tunas pada perbanyakan dengan menggunakan pucuk. Selain itu pada (Gambar 3.b) kontam juga sebagai penyebab kegagalan perkembangan tunas krisan.

Tabel 4. Pengaruh posisi tunas terhadap jumlah tunas, jumlah buku dan jumlah akar.

\begin{tabular}{|c|c|c|c|}
\hline Posisi & Jumlah Tunas & Jumlah Buku & Jumlah Akar \\
\hline Aksilar & $1.14^{\mathrm{b}}$ & $1.17^{\mathrm{b}}$ & $0.44 \mathrm{~b}$ \\
\hline Kontrol & $1.42^{\mathrm{ab}}$ & $1.39^{\mathrm{ab}}$ & $1.07 \mathrm{ab}$ \\
\hline Pucuk & $1.57^{\mathrm{a}}$ & $1.51^{\mathrm{a}}$ & $1.31 \mathrm{a}$ \\
\hline
\end{tabular}

Keterangan: Angka-angka yang diikuti huruf sama pada kolom yang sama tidak berbeda nyata pada uji BNT taraf $5 \%$.

kecil dibanding dengan kontrol.

Secara umum, pada (Tabel 4) menunjukkan perlakuan posisi tunas aksilar dan pucuk berpengaruh nyata terhadap jumlah tunas, jumlah buku dan jumlah akar. Dimana jumlah tunas, jumlah buku dan jumlah akar pada aksilar lebih
Sedangkan jumlah tunas, jumlah buku dan jumlah akar pada pucuk lebih tinggi dibanding dengan kontrol. 


\subsection{Stomata Pada Krisan}

Penyebaran stomata pada tunas krisan terlihat pada (Gambar 7). Terlihat bahwa jumlah stomata pada ex vitro lebih banyak dari pada jumlah stomata pada in vitro. Menurut Prawiranata et al ( 1981), tanaman yang tumbuh pada lingkungan kering dengan intensitas cahaya yang tinggi cenderung memiliki stomata yang banyak tetapi ukurannya kecil dibanding dengan tanaman yang tumbuh pada lingkungan basah dan terlindung.

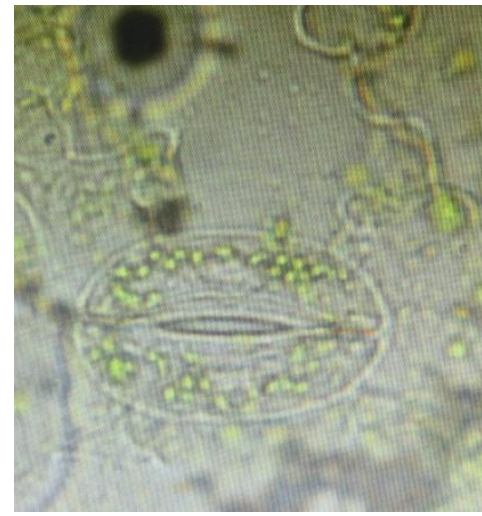

Gambar 7. a. stomata in vitro

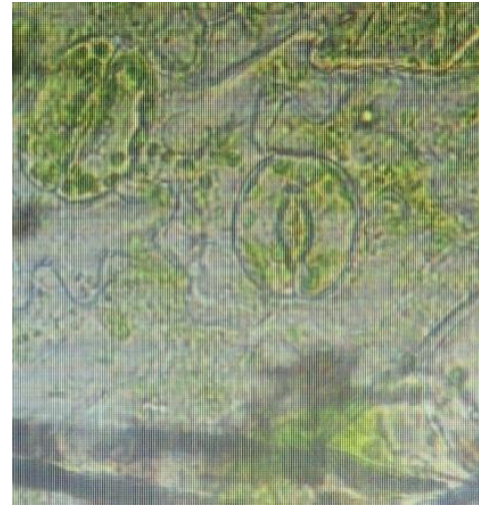

b. stomata ex vitro

Tabel 5. Pengaruh lingkungan invitro dan exvitro terhadap jumlah stomata, lebar stomata dan kerapatan stomata

\begin{tabular}{ccc}
\hline Variabel & In-vitro & Ex-vitro \\
\hline Jumlah Stomata & $54.22^{\mathrm{a}}$ & $71.78^{\mathrm{a}}$ \\
Lebar Stomata & $44620.92^{\mathrm{a}}$ & $37174.23^{\mathrm{b}}$ \\
Kerapatan Stomata & $276.29^{\mathrm{a}}$ & $365.75^{\mathrm{a}}$ \\
\hline
\end{tabular}

Keterangan : huruf yang berbeda menunjukan perbedaan antara perlakuan In Vitro dan Ex Vitro 


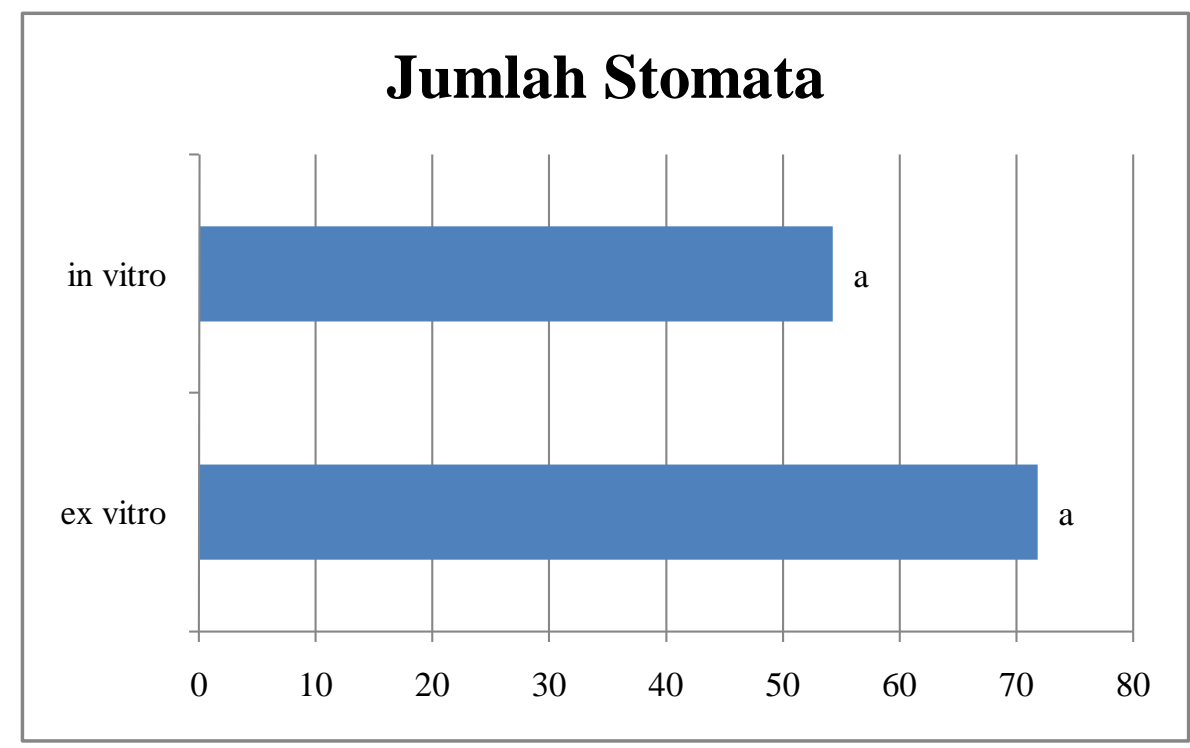

Gambar 8. Grafik Jumlah Stomata

Pada (Gambar.8) terlihat bahwa jumlah stomata daun pada lingkungan ex vitro lebih banyak dari pada invitro.

Menurut Prawiranata et al (1981), tanaman yang tumbuh pada lingkungan exvitro cenderung memiliki stomata yang banyak.

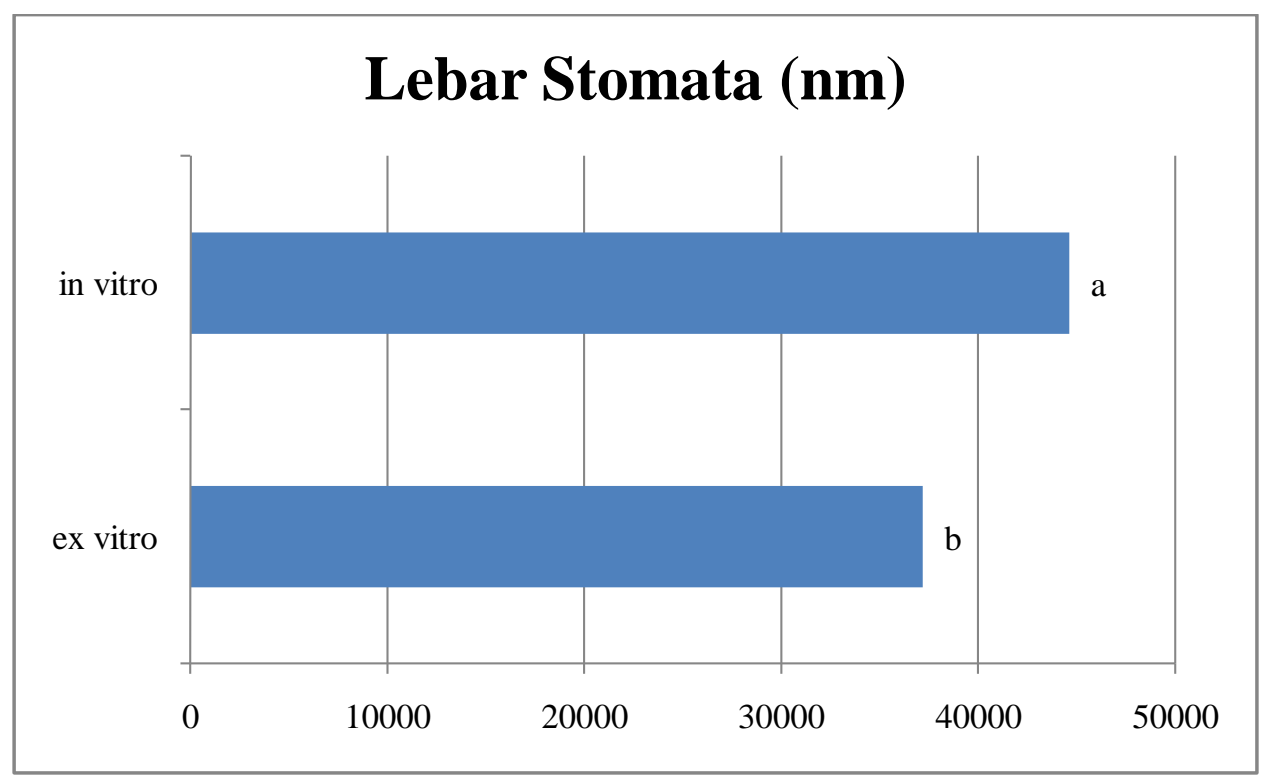

Gambar 9. Grafik Lebar Stomata

Pada (Gambar.9) terlihat bahwa

lebar stomata daun pada lingkungan in vitro lebih tinggi dari pada exvitro. 


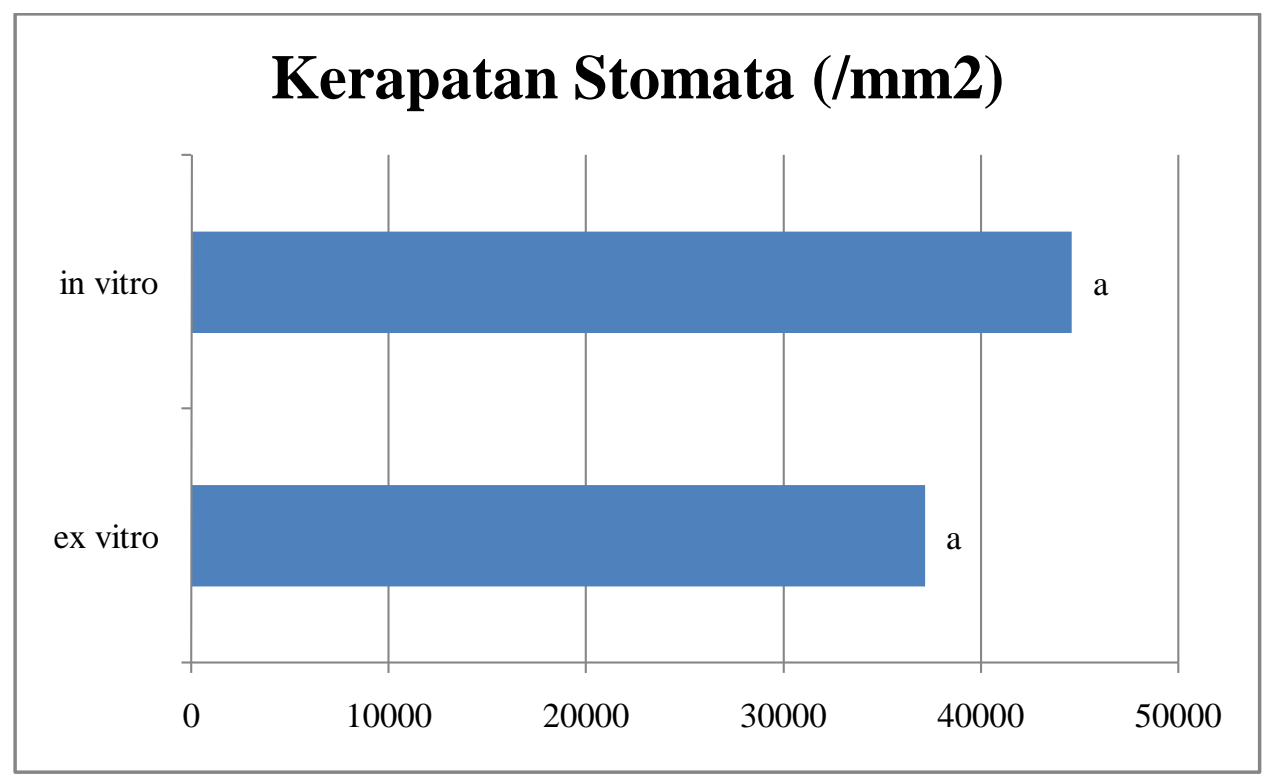

Gambar10. Grafik Kerapatan Stomata

Pada (Gambar.10) terlihat bahwa

KESIMPULAN

kerapatan stomata daun pada lingkungan

in vitro lebih tinggi dari pada exvitro.

Pada (Tabel 5), penyebaran stomata tunas pada perlakuan exvitro berpengaruh nyata pada lebar stomata dengan nilai 37174, 23 lebih kecil dibanding dengan lebar stomata pada invitro yaitu 44620,92. Terlihat pada (Gambar 7) bahwa bentuk stomata dalam kondisi menutup terdapat pada daun krisan yang ditanam pada kondisi Exvitro. Sehingga dapat dikatakan stomata akan berperan sebagai pengatur penguapan

\section{DAFTAR PUSTAKA}

dalam peristiwa fotosintesis. Menurut Palit ( 2008), bahwa aktivitas fotosintesis sangat bergantung pada pembukaan dan penutupan stomata.

1. Perbanyakan secara fotoautotrop melalui pucuk adalah yang terbaik dalam perbanyakan tunas krisan

2. Penyebaran stomata dipengaruhi oleh lingkungan ex vitro dan in vitro, dimana jumlah stomata pada ex vitro lebih tinggi. Sedangkan lebar dan kerapatan stomata yang lebih tinggi terdapat pada daun yang berasal dari in vitro.

Kitaya Y (2005). Importance of air movement for promoting gas and leaf exchange between plants and atmosphere under controlled environment. In: Omassa et al. (eds.) Plant Responses to Air Pollution and Global Change. Springer-Verlag Tokyo. p. 185-193. 
Kozai, T. et al. 1992a. Effect of the difference between photoperiod and darkperiod temperatures, and photosynthetic photon flux density on the shot length and growth of potato planlets in vitro J. Japan Soc. Hort. Sci. J. 61 (1):p. 93-98.

Kozai T \& C Kubota (2005). Concepts, definitions, ventilation methods, advantages and disadvantages. In: T. Kozai et al. (eds.) Photoautotrophic (Sugar-Free

Medium)

Micropropagation As a New MicroPropagation and Transplant Production System. The Netherlands, Springer, p. 19-29.

Lucchesini M, Mensuali-Sodi A, Massai R \& Gucci R. 2001. Development of autotrophy and tolerance to acclimatization of Myrtus communis transplants cultured in vitro under different aeration. Biologia Plantarum. 44:167-174.

Noggle, G. R. and G. J. Fritz 1983. Introductory Plant Physiology. Prentice Hall. P.627.

Palit, J. 2008. Teknik Penghitungan Jumlah Stomata Beberapa Kultivar Kelapa.

Buletin Teknik Pertanian Vol. 13 No. $\quad 1, \quad 2008$. http://pustaka.litbang.deptan.go.id/pu blikasi/bt131083.pdf

Prawiranata, W.S., P. Harran, dan P. Tjondronegoro. 1981. Dasardasar Fisiologi Tumbuhan. Departemen Botani, Fakultas Pertanian Institut Pertanian Bogor.

Rahayu, E.S. 2015. Kultur Fotoautotrofik: Solusi Mikropopagasi Tumbuhan Berkayu. FMIPA Universitas Negeri Semarang. Semarang.
Rukmana, R. Dan A. E. Mulyana. 1997. Krisan. Seri bunga potong. Penerbit kanisius, Yogyakarta.

Woelanningsih, S. 1984. Botani Dasar. Penuntun Praktis Sitologi. Fakultas Biologi. UGM. Yogyakarta. 